\title{
Spatial Lifecycles of Cleantech Industries - the Global Development History of Solar Photovoltaics
}

\author{
Christian Binz* ${ }^{a}$, Tian Tang ${ }^{b}$, Joern Huenteler ${ }^{c}$ \\ *Corresponding author: christian.binz@circle.lu.se \\ a-Centre for Innovation, Research and Competence in the Learning Economy - CIRCLE, Lund \\ University, Lund, Sweden \\ $b$ - Askew School of Public Administration and Policy, Florida State University, Florida, USA \\ c-The World Bank, Washington DC, USA
}

\begin{abstract}
New industries develop in increasingly globalized networks, whose dynamics are not well understood by academia and policy making. Solar photovoltaics (PV) are a case in point for an industry that experienced several shifts in its spatial organization over a short period of time. A lively debate has recently emerged on whether the spatial dynamics in new cleantech sectors are in line with existing industry lifecycle models or whether globalization created new lifecycle patterns that are not fully explained in the literature. This paper addresses this question based on an extensive analysis of quantitative data in the solar PV sector. Comprehensive global databases containing 86,000 patents as well as manufacturing and sales records are used to analyze geographic shifts in the PV sector's innovation, manufacturing and market deployment activities between 1990 and 2012. The analysis reveals spatial lifecycle patterns with lowerthan-expected first mover advantages in manufacturing and market activities and an earlier entry of firms from emerging economies in manufacturing and knowledge creation. We discuss implications of these findings for the competitive positions of companies in developed and emerging economies, derive new stylized hypotheses for industry lifecycle theories, and sketch policy approaches that are reflexive of global interdependencies in emerging cleantech industries.
\end{abstract}

Keywords: industry lifecycle, product lifecycle, patent analysis, solar photovoltaics 
Binz, Tang, Huenteler - Spatial Dynamics in the Knowledge Base of Cleantech Sectors

\section{Introduction}

In the globalizing knowledge economy, industry lifecycles are getting subject to increasing spatial complexity (Bunnell and Coe, 2001; Crevoisier and Jeannerat, 2009; Ernst, 2002; Gallagher, 2014; Quitzow, 2013). This observation is particularly relevant for many recently emerging clean-tech sectors: Empirical studies in the solar power, wind power, water recycling or urban transportation sectors all suggest that knowledge and other key resources for emerging industries are increasingly circulating between places and getting mobilized by a diverse set of actors around the world (Binz et al., 2014; Lewis, 2011; Quitzow, 2013; Sengers and Raven, 2015). This has far reaching consequences for policy-making and innovation theories. In particular, well-established industry lifecycle theories are challenged to explain the rapid spatial shifts in key growth sectors, e.g. from Western countries to Asia or from developed to developing economies.

In the past, firms in developed countries that led new products' and industries' early innovation and manufacturing efforts often achieved sustained first mover advantages (Abernathy and Utterback, 1978; Beise and Rennings, 2005; Klepper, 1996). Industrial and innovation policies accordingly focused on creating lead markets and lead manufacturers in specific national or regional contexts (Anadón, 2012; Beise and Rennings, 2005; Lundvall, 1992; Lundvall et al., 2002). In today's globally interconnected knowledge economy, the effectivity of such national initiatives is increasingly questioned (Dicken, 2007; Pietrobelli and Rabellotti, 2009; Quitzow, 2013). In particular, emerging economies in Asia, and especially China and India, have become significant competitors in global clean-tech industries over a very short period of time and are now starting to challenge Western technology leadership (Nahm and Steinfeld, 2014; Peters et al., 2012).

Solar photovoltaics (PV) are a case in point for a sector that emerged in a highly globalized pattern with a significant shift of activity towards emerging economies, and in particular China (Quitzow, 2013; Varadi, 2014). By 2016, more than 70 percent of crystalline PV panel manufacturing was concentrated in China and Taiwan, and also the upstream and downstream parts of the value chain were increasingly shifting towards Asia (Gallagher and 
Binz, Tang, Huenteler - Spatial Dynamics in the Knowledge Base of Cleantech Sectors

Zhang, 2013; Gress, 2014). A lively debate has emerged in the literature about whether this spatial shift can be conceptualized with existing industry lifecycle theories or whether it constitutes a new pattern of catching-up that asks for improved theoretical explanation (Binz and Diaz Anadon, submitted; Gallagher and Zhang, 2013; Nahm and Steinfeld, 2014; Quitzow, 2015; Schmidt and Huenteler, 2016).

So far, most work that has addressed this question based on in-depth case studies. A more quantitative assessment of the spatial dynamics in the solar PV sector and other emerging cleantech sectors is still largely missing. Also, existing theorizing explains lifecycle dynamics mostly from the supply-side (manufacturing), while downplaying the importance of co-evolving knowledge creation and market deployment processes. This paper aims at addressing this gap based on an in-depth analysis of patenting, manufacturing and market deployment data in the global solar PV sector and juxtaposing it with findings from existing industry lifecycle literature. In this venture, two main research questions guide the analysis: 1) How did the location of innovation, manufacturing and market deployment in the solar PV industry evolve over time? 2) How would existing industry lifecycle theories have to be adapted to explain the spatial dynamics in the PV sector (and other clean-tech industries with similar properties)? These questions are explored based on a comprehensive global patent dataset containing 86,000 PVrelated patents from the 50 major patent offices around the world over the period 1965-2012, as well as on a collection of manufacturing and market deployment data for key countries from 1990-2012. The data is analyzed for spatial shifts in innovation, manufacturing and deployment centers related to each other in different phases of the industry lifecycle.

The remainder of the paper is structured as follows: We first introduce current industry lifecycle theories and identify gaps in this literature's conceptualization of co-evolving innovation-, manufacturing-, and market dynamics. Section 3 introduces the cases study, database and methods before exploring the global lifecycle patterns of the PV sector in detail in section 4. Sections 5 and 6 discuss the implications of our findings for lifecycle theories as well as for policy making in cleantech sectors and introduce promising future avenues of research. 
Binz, Tang, Huenteler - Spatial Dynamics in the Knowledge Base of Cleantech Sectors

\section{State of the Art}

Spatial shifts in the organization of industries are of key importance for national and regional development (Storper and Walker, 1989). Several streams of literature have developed hypotheses on how and why an industry's knowledge base, manufacturing base, and markets shift in space. Among the various approaches from evolutionary economics and economic geography, this paper analyzes two approaches in more detail: product and industry lifecycle approaches (Abernathy and Utterback, 1978; Klepper and Graddy, 1990; Klepper, 1996).

\subsection{Existing theories on spatial lifecycle dynamics in new industries}

Product and industry lifecycle approaches predict that over the maturation of a product or industry, three stylized development phases follow each other that differ in their spatial setup (Vernon, 1966): In the very early, 'fluid', phase, inventors experiment with a new to the world idea. Uncertainty is high, user needs are unclear, manufacturing volumes are low and small entrepreneurial firms compete with each other based on frequent product design innovation (Abernathy and Utterback, 1978; Vernon, 1966). Early companies depend on flexible inputs, well-trained labor and dense user-producer interaction. This first lifecycle phase accordingly depends on narrowly confined geographic areas where early user needs and product innovations get aligned through regular face-to-face interaction. The initial region where an industry develops (usually located in a developed economy) is consequently assumed to possess significant locational advantages also in later development stages (Klepper, 1996; Vernon, 1966).

In the subsequent 'transitional' phase of a maturing product, innovation dynamics change. Manufacturing volumes start rising, the innovation gets more standardized and new entrants and specialized suppliers enter the industry (Abernathy and Utterback, 1978). Search processes shift from product innovation to process innovation; parts of the manufacturing process get automated, and firms increasingly try to reap economies of scale while decreasing input factor costs (Utterback and Abernathy, 1975). A first spatial shift in the industry accordingly happens in this phase: As markets for the innovation develop in foreign countries, 
Binz, Tang, Huenteler - Spatial Dynamics in the Knowledge Base of Cleantech Sectors

the initial inventors will consider establishing manufacturing plants abroad (Vernon, 1966). As the manufacturing process is still relatively complex and prone with uncertainty, manufacturing will be outsourced to other developed countries with slightly lower labor costs, but sufficient supply of well-trained social capital (ibid.). In some cases, international subsidiaries of the initial firms will start exporting to third party markets or even back to the original region.

In the final development phase of a 'standardized product', a dominant design and mass markets with well-articulated user needs emerge. Activities in the industry now evolve around incremental process innovation and manufacturing is organized in highly automated, capitalintensive, large scale plants (Abernathy and Utterback, 1978; Vernon, 1966). As economies of scale play an increasingly important role, a shakeout occurs and less efficient producers exit the industry (Klepper, 1996). In this last phase, locational dynamics shift towards developing/emerging economies with significantly lower factor prices (especially labor costs) and additional untapped market potential (Klepper and Graddy, 1990; Vernon, 1966). Usually, only low value-added and highly standardized manufacturing processes get outsourced to developing economies while more complex parts of the value chain remain concentrated in firm headquarters in the initial region (Abernathy and Utterback, 1988; Vernon, 1966).

The validity and use of this analytical framework has been confirmed with a broad set of conceptual and empirical studies (Abernathy and Utterback, 1988; Anderson and Tushman, 1990; Klepper, 1996; Suarez and Utterback, 1993; Vernon, 1966). Yet, lifecycle concepts have also been criticized on various grounds, some of which are of key significance for the locational dynamics of emerging cleantech industries. We here focus on one key line of thought, which posits that the literature has emphasized the supply side (manufacturing processes and the emergence of dominant designs), while downplaying the demand side (market diffusion and the active construction of new market segments) and knowledge network's role in the spatial dynamics of new industries (Jeannerat and Kebir, 2016; Malerba, 2006; Murmann and Frenken, 2006). A key open question in lifecycle literature accordingly is whether and how spatial shifts in manufacturing activities co-evolve with shifts in knowledge networks and market deployment (Malerba, 2006). 
Binz, Tang, Huenteler - Spatial Dynamics in the Knowledge Base of Cleantech Sectors

In terms of innovation activities, traditional lifecycle literature assume somewhat simplistically that key knowledge centers remain concentrated in the initial regions as firms outsource only manufacturing, but not innovation, design and management functions to latecomer regions (Dicken, 2007; Utterback and Abernathy, 1975; Vernon, 1966). Especially latecomers in emerging economies enter knowledge networks only in the latest development phase when a dominant design and standardized manufacturing processes have emerged. They are expected to remain in a lagging position for extended periods of time, as they have to absorb outside knowledge in a long-term technology transfer and capability upgrading process (Gereffi, 1999; Morrison et al., 2008).

Similar assumptions are put forward for the market dimension, where the initial markets of a new industry (often 'lead markets' in developed economies) retain a key role throughout all phases of the industry lifecycle (Klepper and Graddy, 1990; Vernon, 1966). Lead market literature posits that regions which develop first mass markets for a new product will not only retain significant market shares over time, but also profit from sustained first mover advantages in the knowledge and manufacturing dimension (Beise and Rennings, 2005; Jänicke and Jacob, 2004). As latecomers to an industry will be reliant on the specialized knowledge developed in lead markets, the first mover will retain its central network position for a long period of time, even if competition emerges in other places around the world (ibid.).

\subsection{Stylized spatial lifecycle model of manufacturing, knowledge creation and markets}

Based on the short literature review above, a stylized model can be derived on how manufacturing capacity, knowledge base, and market shares develop in space in the traditional technology lifecycle model (see Figure 1, 2, 3). First, manufacturing capacity is expected to experience strong spatial shifts from the pioneering to follower regions: Whereas initially manufacturing is spatially concentrated in one region, in the transitional phase, activities shift to early followers in other developed economies. In the subsequent standardized product phase, low value-added parts of the value chain are further relocated to late follower regions in developing countries (Figure 1), leaving the pioneering country with significant losses of its 
Binz, Tang, Huenteler - Spatial Dynamics in the Knowledge Base of Cleantech Sectors

initial manufacturing shares. In many cases, it will however retain key manufacturing capacity in higher value-added upstream and downstream value chain segments, like R\&D functions, advanced manufacturing of materials or components, and the installation, operation and aftersales services (Zhang and Gallagher, 2016).

$<<$ insert figure 1 about here >>

Considering market shares, the initial lead market will grow most quickly and be the first to get saturated. Early follower's markets develop quickly after the lead market and eventually achieve saturation towards the end of the standardized phase. Late followers in emerging economies are expected to develop significant demand only in the latest lifecycle phase, without reaching saturation (Figure 2). Overall, market shares trickle down from developed to developing economies in a gradual process.

<<insert figure 2 about here>>

Knowledge, finally, is equally expected to show strong spatial path dependency. Key knowledge is developed in a pioneering country which then keeps a dominant role in knowledge-intensive forms of innovation (e.g. patenting and design) over time (Figure 3). While early and late followers might equally invest in R\&D and develop technological capabilities, the pioneering region will retain a key competitive advantage due to cumulative and territorially embedded knowledge spillovers in the innovation systems and industrial districts forming around new industries (Moulaert and Sekia, 2003; Storper, 1997). This effect may decrease only in the transitional and standardized phases, when tacit knowledge exchange in clusters loses its central importance (Audretsch and Feldman, 1996). Still, evolutionary theories in economic geography posit that key product and process innovations in later lifecycle stages will branch out from recombining related knowledge bases, thus remaining concentrated in regions that already provide substantial related variety in their knowledge bases (Boschma and Martin, 2010; Neffke et al., 2011). Competitive advantages in knowledge manufacturing 
Binz, Tang, Huenteler - Spatial Dynamics in the Knowledge Base of Cleantech Sectors

thus remain relatively stable over time, with limited spatial diffusion in e.g. patent activities.

$<<$ insert figure 3 about here>>

\subsection{Applying a lifecycle perspective to cleantech industries}

Overall, the stylized models presented above expect the pioneering region to retain an important role in all three domains, while following regions build up lower value-added manufacturing capacity, gain market shares only in price-competitive segments of the value chain and keep lagging the global technology leader regions in terms of patenting over extended periods of time. In particular the early co-location of knowledge creation, manufacturing and market deployment in specific regions or countries is expected to produce spillovers and economies of scale that are hard to copy elsewhere and thus remain sticky in space (Asheim et al., 2007; Moulaert and Sekia, 2003). This view has only recently come under increasing scrutiny from authors that argue that geographic proximity in innovation and manufacturing can increasingly be substituted with other forms of cognitive, organizational, social and institutional proximity (Boschma, 2005).

Recent empirical studies in cleantech sectors are a case in point. Several authors hint at quite dramatic spatial shifts not only in manufacturing, but also in the knowledge base and key markets of the wind power (Bento and Fontes, 2015; Lema and Lema, 2012; Lewis, 2011), water recycling (Binz et al., 2014) or solar photovoltaics industries (Dewald and FromholdEisebith, 2015; Quitzow, 2015). Authors highlight that supply-side driven spatial lifecycle theories are particularly problematic for cleantech sectors in which knowledge creation and market formation are heavily influenced by demand-side dynamics and public policy interventions (Binz et al., under review; Quitzow, 2015). In the remainder we accordingly aim at exploring how knowledge creation activities co-evolve in space with manufacturing and market deployment to derive whether and how lifecycle theories (and related policy advice) would need to be adapted to better reflect the specific context of emerging clean-tech sectors. The next 
Binz, Tang, Huenteler - Spatial Dynamics in the Knowledge Base of Cleantech Sectors

section will shortly discuss why the solar PV sector was chosen as an empirical case to take a first step in this conceptual endeavor.

\section{Case Selection and Methods}

\subsection{Case Selection}

Solar PV systems produce renewable energy through converting the electromagnetic spectrum of sunlight into electrical power. The electric power generated by PV systems can be consumed right on the spot where the system is installed, or be fed into the electric power grid. The value chain of Solar PV module production includes multiple steps, which can be separated into three generic segments - upstream, core and downstream (also see Zhang and Gallagher, 2016). The upstream segment comprises silicon production, which is extracted from molten sand and then purified, cast into ingots and cut into slices of a few hundred micrometers thickness, the wafers. In the core segment of the value chain, the wafers are cleaned, coated, and covered with thin silver paste contacts to produce solar cells, which are then combined to form solar modules - the core of a solar PV system. In the downstream value chain segment, solar modules are combined with inverters, mounting systems and power management systems to form a complete PV power plant. Plant engineering, construction, after sales operation and maintenance are also part of the downstream value chain segment.

The solar PV industry was chosen to represent an extreme case that directly contradicts some basic assumptions of traditional industry lifecycle literature: Its knowledge base emerged in a globalized setup from the very early industry formation phase (de la Tour et al., 2011; Peters et al., 2012; Varadi, 2014) and the industry reportedly saw several strong shifts in the geographic locations of its key manufacturing and market places over rather short periods of time (Binz and Diaz Anadon, submitted). These shifts were recorded with particularly comprehensive datasets that provide unique insights into global knowledge, manufacturing and market formation dynamics of an emerging sector. Given the technology characteristics described above, we treat solar PV as a paradigmatic example for the lifecycle dynamics in industries with mass-produced, standardized goods (Huenteler et al., 2016). Differences for the 
Binz, Tang, Huenteler - Spatial Dynamics in the Knowledge Base of Cleantech Sectors

industry lifecycle patterns in industries with more complex products and systems (e.g. wind power, electric cars) will be shortly elaborated in the discussion and left for future research.

\subsection{Data and methods}

To describe and analyze the spatial lifecycle dynamics of the solar PV industry, data on the global distribution of manufacturing, market deployment and knowledge creation was collected from the following databases. The knowledge dimension is operationalized with patent data derived from the Thomson Innovation and Derwent World Patent Index global patent databases. Patents relevant to solar PV were identified using a search string that combined PV-related patent classes from the International Patent Classification (IPC) system ${ }^{1}$ with solar PV-related key words. ${ }^{2}$ If the owner of a single invention files patent applications in multiple countries to protect this invention in those countries, all patent applications in the same patent family were recorded as one observation. Patent records were dated by the priority date, the earliest application date for the invention at any patent office worldwide, which corresponds most closely to when the knowledge was actually created.

Our search string returned a database of 87,000 patents with priority dates from 1965 to 2012. Solar PV patents were further divided into three value chain segments, differentiating between technologies in the upstream, core, and downstream value chain segments (table 1). This classification is based on the IPC codes of each patent. The IPC codes within each value chain segment are shown in Table 1 and in more detail in Appendix 1. Patent records comprise information about the inventors, its affiliation, abstracts, as well as citation counts and patent family size which were used to construct patent quality measures.

\footnotetext{
${ }^{1}$ A detailed description of each 4-digit IPC code in our search string is listed in Appendix 1.

2 Search string: $\mathrm{IP}=\left(\mathrm{B} 23 \mathrm{~K}^{*}\right.$ or $\mathrm{B} 28 \mathrm{D} *$ or $\mathrm{C} 01 \mathrm{~B} *$ or $\mathrm{C} 23 \mathrm{C}^{*}$ or $\mathrm{C} 30 \mathrm{~B} *$ or $\mathrm{E} 04 \mathrm{D} *$ or $\mathrm{H} 01 \mathrm{~B} *$ or $\mathrm{H} 01 \mathrm{~L} *$ or $\mathrm{H}_{01 \mathrm{M}}^{*}$ or $\mathrm{H}_{01 \mathrm{G}}^{*}$ or $\mathrm{H} 02 \mathrm{M}^{*}$ or $\mathrm{H} 02 \mathrm{~J}^{*}$ or $\mathrm{H} 02 \mathrm{~N}^{*}$ or $\mathrm{H} 01 \mathrm{R}^{*}$ or $\mathrm{G} 01 \mathrm{~B} *$ or $\mathrm{G} 01 \mathrm{R}^{*}$ or $\mathrm{G} 05 \mathrm{~F}^{*}$ or $\left.\mathrm{G} 06 \mathrm{~F}^{*}\right)$ and TS=("solar cell*" or "solar power*" or "solar module*" or photovoltaic* or "solar panel*" or "solar electr*" or (solar and (semiconduct* or wafer* or ingot*))). The first part of the string includes all 4-digit IPC codes related to solar PV technologies. Within all the patents found through these IPC codes, we further searched key words - "solar cell", "solar power", "solar module", "solar photovoltaic", "solar panel", "solar electric", "semiconduct", "solar wafer", and "solar ingot" - in their titles and extracted the patent records that contain any of these key words in the titles.
} 
Binz, Tang, Huenteler - Spatial Dynamics in the Knowledge Base of Cleantech Sectors

<<insert table 1 about here>>

\section{Results: Spatial Lifecycle Dynamics in the Solar PV Sector}

Based on recent work by Dewald and Fromhold-Eisebith (2015) we separate the lifecycle of the solar PV industry into three phases as follows: A fluid phase between 1965 and 1990, a transitional phase between 1990 and 2005 and a standardized phase from 2005 until today. Before 1990, most activities in the industry were experimental and exploratory, a dominant design had not yet emerged and various small firms entered and exited the industry (Dewald and Fromhold-Eisebith, 2015; Varadi, 2014). Between 1990 and 2005, a dominant design and first mass-markets for the technology emerged and new companies entered the industry all over the world (Dewald and Truffer, 2011; Dewald and Fromhold-Eisebith, 2015; Hoppmann et al., 2014). After 2005, a consolidation and shakeout occurred and PV modules increasingly turned into a globally standardized commodity for uniform global mass markets (Hoppmann et al., 2014; Quitzow, 2015). This general pattern will now be explored in more detail for each of our analytical dimensions, manufacturing, market formation and knowledge creation.

\subsection{Spatial dynamics in PV manufacturing}

From 1965-1990, manufacturing in the PV field was largely limited to two pioneering countries, the USA and Japan. Originally, PV panels were manufactured mostly for powering satellites and other specialized space applications (Varadi, 2014). Starting from the 70ies, pioneering companies in the US and Japan started experimenting with terrestrial applications of PV panels on antennas, weather stations, oil rigs, navigation buoys, calculators, educational toys, etc. (Varadi, 2014). Until the late 80ies manufacturing volumes remained very low, product designs varied strongly and most of the input materials were leftovers from the semiconductor industry. 
Binz, Tang, Huenteler - Spatial Dynamics in the Knowledge Base of Cleantech Sectors

The fluid phase is accordingly not covered with comprehensive manufacturing or deployment data. $^{3}$

Reliable manufacturing records start in the transitional phase (early 1990ies) when the technology got standardized to some degree and manufacturing shifted to early latecomer countries, particularly in Japan and Europe. After the Reagan administration significantly cut PV manufacturing subsidies in the USA (1981-1984), many of the pioneering PV manufacturers got bought by transnational oil companies or their competitors in Germany and France (Varadi, 2014). Figure 4 shows that from the early days of the standardization phase, US manufacturing shares started declining, while Japan managed to retain significant manufacturing capacity until the late 2000s. Germany built up significant manufacturing volumes in the later transitional phase, which however declined again steeply in the late 2000s (also see Hoppmann et al., 2014).

Starting from the mid-2000s, the most dramatic spatial shift happened in the global distribution of manufacturing capacities as China quickly ramped up PV cell and module manufacturing capacity and took over dominant global manufacturing shares (Binz and Diaz Anadon, submitted; Quitzow, 2015). Starting in the transitional phase, Chinese companies went from almost $0 \%$ market share to supplying more than $60 \%$ of global PV cell output (with overall global production volumes exploding at the same time, see figure 4). With the steep rise of Chinese competitors, a shakeout occurred in the global PV industry that continued in the standardized phase. Several German and Japanese manufacturers went bankrupt or subsequently specialized in upstream (silicon, turnkey manufacturing lines) market segments, while US producers specialized in technologically more advanced niche technologies (e.g. thin film) and innovative installation and maintenance business models in downstream value chain segments.

<<insert figure 4 about here>>

\footnotetext{
${ }^{3}$ Existing data for the fluid phase only records the annual global solar PV cell manufacturing and manufacturing in the USA. According to this data, the total production over this period (1965-1990) is $0.275 \mathrm{GW}$, which is only approximately $5 \%$ of the total solar PV cell production in the second phase and the production from US account for $34 \%$ of the total production in this initial stage. Records on solar PV manufacturing in Japan can be dated back to 1980s, as shown in Figure 4.
} 
Binz, Tang, Huenteler - Spatial Dynamics in the Knowledge Base of Cleantech Sectors

\subsection{Spatial dynamics in PV markets}

Similar to manufacturing data, also records on PV market deployment are incomplete in the fluid phase. Between 1965 and 1990, most markets for PV products were small-volume niche markets with unclear future development prospects (Varadi, 2014). The existence of variegated niche markets proved crucial for experimentation, learning and technology standardization in the pioneering firms between 1970 and 1985, but played a minor role for later industry lifecycle phases (ibid.).

Significant and targeted market deployment policies emerged only in the transition phase (after 1990) in Japan and the EU (Vasseur et al., 2013). Figure 5 accordingly shows that market deployment of solar PV modules was concentrated in the EU and Japan for most of the transition phase. A crucial event for the global PV sector was the implementation of a massive market deployment subsidy in Germany in 2001, the national feed-in tariff (FIT) (Hoppmann et al., 2014; Quitzow, 2015). This policy provided guaranteed tariffs for electricity fed into the power grid from renewable energy power plants and essentially created the world's first mass market for commercial and private solar PV systems. Other European governments (e.g. in Italy and Spain) were fast in copying this policy approach (Dewald and Truffer, 2011), so by 2010 about $80 \%$ of global PV market deployment happened in the EU (see figure 5).

$<<$ insert figure 5 about here >

As in the manufacturing dimension, we see a significant shift also in PV market deployment around 2010. In the aftermath of the global financial crisis in 2008 and the dislocation of most PV manufacturing activities from the EU to China, the European FIT systems lost political legitimacy and deployment subsidies got significantly cut back (Hoppmann et al., 2014; Quitzow, 2015). As a consequence, the Chinese government was forced to support its large manufacturing industry with a domestic PV deployment program. At the same time, increasing manufacturing and market volumes meant that PV prices decreased to a level where the technology was close to achieving grid-parity with other power generation 
Binz, Tang, Huenteler - Spatial Dynamics in the Knowledge Base of Cleantech Sectors

technologies. In the standardized lifecycle phase after 2010, Japan, China, the USA and various other countries thus developed their own support policies that encouraged widespread PV deployment. By 2015 the solar PV market had become globally standardized to a large degree with deployment shares spread more or less equally between countries in the Americas, Europe, and Asia.

\subsection{Spatial dynamics in PV knowledge generation}

\subsubsection{Overview of spatial shift in knowledge generation}

Figure 6 provides an overview of spatial shift in knowledge generation for the solar PV industry. As a first step, patenting activities are measured in the form of annual total patent counts at country level or global level. At a global level, patenting activity increases exponentially, particularly in the transition phase after 2005. Among all three value chain segments, most patenting activities focus on core technologies (technologies related to solar cell or module manufacturing), while patents related to upstream technologies (such as silicon, ingots, and wafer sawing) only account for a very small portion of the knowledge base.

<<insert figure 6 about here>>

At a country level, Japan and the US took the lead in patenting activities in the first and second phases with Japan possessing more than $50 \%$ of the total patents in the world. During these two phases, Germany was also a major knowledge base. Other Asian countries, such as China and South Korea started patenting activities towards the end of the transition phase. Patent shares decline for pioneering countries like Japan and US while latecomers such as China and Korea catch up with considerable shares of patents in the third phase. Particularly, Chinese patents account for almost $80 \%$ of global patenting in 2011-2012. 


\subsubsection{Quality measures for the spatial shift in knowledge creation}

The total patent counts above only reflect patenting activity from a quantitative perspective. To meaningfully compare knowledge generation activities across countries, a quality measures in the form of quality-quantity matrixes is thus included (see Figure 7). Following previous patent studies, the number of forward citations and patent family size were used as patent quality measures. Global patent counts are used as an indicator for patent quantity in the matrix, but further separated into three value chain segments (i.e. upstream, core, and downstream technologies) based on their IPC codes classified in Table 1. Results for knowledge base shifts are shown in Figures 7-1 to Figure 7-3 respectively.

Our first quality indicator is a patent's number of forward citations. During patent application, the applicant needs to cite existing relevant patents in order to demonstrate its novelty and contribution to relevant technologies. This number of citations a patent has from its successive patents was used to measure its importance and relevance in the field (Harhoff et al., 2003). To exclude the influence of citation time lag and depreciation ${ }^{4}$, we normalize the forward citations for each patent by the average forward citations for all patents filed globally in the same year. Through this procedure we derive the average citations for all patents filed during each phase of the lifecycle at country level. ${ }^{5}$ Our second quality indicator is patent family size, which refers to the number of publications of the same patent in multiple countries by common inventors. If an invention is expected to be technologically important, it may be used in multiple countries and have high economic value. Therefore, its owner is usually willing to file costly patent applications in more than the originator country to protect this invention internationally (Lanjouw et al., 1998). Empirical evidence also supports that large international patent families are particularly valuable (Harhoff et al., 2003). Among all countries where a specific technology

\footnotetext{
${ }^{4}$ Since our data was collected in 2013, patents filed in more recent years have fewer citations because the data does not allow enough time to accumulate forward citations. In addition, older patents are also depreciated, or even become obsolete over time. Thus, we observe that patents in transitional phase, on average, receive more forward citations than patents filed in other two periods, as shown in Appendix 2. Particularly, patents filed after 2000 have comparatively low citations. For patent family size, we observe a similar pattern in Figure A2b). Thus, we also normalize patent family size in Figure 7.

${ }^{5}$ With this normalized measure, citation number that is larger than 1 indicates that the average quality of patents in a particular country is higher than the global average patent quality in the same period. Thus, the knowledge created in this particular country has (relatively) high quality in our matrix.
} 
Binz, Tang, Huenteler - Spatial Dynamics in the Knowledge Base of Cleantech Sectors

is protected, the priority country where the invention was originally created would be regarded as the knowledge base for this technology. Similar to forward citation, we also adopt the normalized patent family size in the quality-quantity matrix. As shown in Figure 7, both quality measures lead to similar results for the evolution of major knowledge bases. Three main trends stick out from this analysis:

1) The two pioneering countries (the major knowledge bases since the first phase of solar PV lifecycle), Japan and the US, accounted for the largest shares of patents in all three technology segments throughout the first and second phases. Although their shares decline in the third phases as China's patent counts ramp up from the mid-2000s, Japanese and US actors still retain considerable global patenting shares. However, the two pioneering countries show different patterns of knowledge creation. While Japan keeps a high profile in patent quantity, its patents on average have relative low quality in the fluid and transitional phase compared to US and German competitors, and moderate quality in the standardized phase in all segments. In contrast, US patent numbers are lower, but retain higher quality measures throughout the lifecycle in all value chain segments, particularly for core and downstream technologies.

2) The first and most relevant early follower country in our dataset, Germany, shows significantly lower patent counts than the US and Japan in the upstream and core value chain segments in all three phases. Yet, patenting shares in the downstream value chain segment are comparable with the USA in the first two phases. While the share of German patents in all three segments keeps declining over time, the patents retain relatively high quality in all segments, especially for upstream (silicon casting, turnkey manufacturing lines) and downstream (balance of systems, after-sales services, energy storage) types of activity.

3) Among latecomers from emerging economies, China's patent quantity increased sharply from the end of the transition phase (mid-2000s) in each technology segment with concentration in core and downstream technologies. While the quality of Chinese patents has slightly improved over time, the average forward citations and family size of Chinese patents remain the lowest of all analyzed knowledge bases. Another late follower, South Korea, also ramped up its patent quantity during the third phase, and possessed considerable share of patents 
Binz, Tang, Huenteler - Spatial Dynamics in the Knowledge Base of Cleantech Sectors

in each technology segment after 2010. Yet, unlike China, Korean patents also enjoy moderate to high levels of quality in terms of patent family size. Particularly, it has high quality patents in upstream technologies according to both measures.

\section{Discussion}

When comparing the spatial evolution of the solar PV market, manufacturing and knowledge bases with the stylized model in section 2.2, two main findings stand out.

First, in industries like solar PV, first mover advantages in the manufacturing dimension seem to be less persistent over time and space than expected (also see Appendix 3). Early technology pioneers in the USA and Japan dominated global manufacturing until the mid 1990ies, but then almost completely lost module manufacturing shares to European and subsequently Chinese competitors. Especially pioneering US companies (i.e. Solarex, Spectrolab, Arco Solar) experienced a thorough loss of manufacturing capacity starting from the mid-80s after policy support was cut for the emerging solar PV industry (Varadi, 2014). Also the timing, speed and magnitude of catching-up by Chinese manufacturers between 2000 and 2010 contradicts theoretical assumptions: While industry lifecycle theory expects actors from developing countries to enter only in the standardized phase (and as subsidiaries of firms from developed economies), Chinese actors entered the PV field already in the transitional phase and played an active role in framing the dominant design, automatizing the manufacturing process and reducing panel costs by an order of magnitude (Binz and Diaz Anadon, submitted; Dewald and Fromhold-Eisebith, 2015; Quitzow, 2015). In contrast to industry lifecycle theory, manufacturing costs were not primarily reduced through low labor costs, but more importantly by automating the manufacturing process and developing supplier clusters in China that delivered low-cost factor inputs (Goodrich et al., 2013; Nahm and Steinfeld, 2014). Overall, the spatial diffusion pattern of manufacturing activities is not the expected linear trickling down from pioneering to following countries, but rather radical breakdown of industrial activities in one place followed by a boom elsewhere.

A second contradiction with lifecycle theories exists in the market dimension: Initial niche markets were as expected concentrated in the pioneering manufacturing and innovator 
Binz, Tang, Huenteler - Spatial Dynamics in the Knowledge Base of Cleantech Sectors

countries, in particular in the USA and Japan (where also manufacturing and knowledge creation was booming between 1970 and 2000), but slumped in relative importance during the transition phase. Thus, instead of a sustained lead market advantage we observe a thorough spatial shift of PV lead markets in the transition and early standardized phase from the USA and Japan to Europe. The initial lead markets regained relevant market shares only in the standardized phase - in Japan as a response to the Fukushima accident in 2011 and in the USA after PV panel prizes reached near-grid-parity levels. Policy interventions appear to explain most of the higher than expected spatial volatility in the market dimension. Large scale deployment policies like the feed-in tariff system (FIT) in Germany and Spain enabled the shift to Europe in the transition phase, while tax credit incentives (USA) and a FIT system in Japan re-established demand in the initial lead markets after 2010 (Hoppmann et al., 2014; Huenteler et al., 2012; Peters et al., 2012).

In more general terms, we observe a more erratic spatial diffusion pattern than the relatively linear and cumulative model in ILC theories would suggest. Only in the knowledge dimension, interestingly, we identified spatially more or less stable and cumulative development patterns: knowledge creation started in the USA and Japan and both countries retained leading patenting shares (though with significant differences in quality) throughout the industry life cycle. European actors took over considerable patenting shares in the 90ies and 2000s, but never reached the same (relative) output levels as the early technology pioneers. Late followers, especially in China and to a lesser degree Korea, have ramped up their absolute patenting counts since the mid-2000s, yet with consistently lower quality measures than their European, Japanese and US competitors in most segments of the value chain. Interestingly, knowledge creation and technology innovation dynamics remained largely unaffected by the high spatial volatility in the market and manufacturing dimensions. As a result of these diverging lifecycle patterns we observe a global division of innovation, manufacturing and market deployment activities from the mid-2000s: China (including Taiwan) has essentially replaced the US and Japan as the global manufacturing center for PV cells and modules (core parts of the value chain). The USA (and to some degree Japan) still dominate knowledge creation, particularly in terms of patent 
Binz, Tang, Huenteler - Spatial Dynamics in the Knowledge Base of Cleantech Sectors

quality, but now host only few major cell and module manufacturers. European countries turned into the major consumers of solar PV products, while retaining most expertise in the upstream (silicon casting, turnkey manufacturing lines) and downstream (balance of systems, after-sales services, energy storage) segments of the value chain.

These findings imply that in industries like solar PV, spatial co-location of manufacturing, markets and manufacturing is a less pervasive phenomenon than expected. Over the lifecycle of the PV industry, patenting, manufacturing and market deployment have more often been spatially dispersed than densely co-located. Only at the very early stage of the industry (in the 70ies-early 80ies) and shortly in the late 90ies were all three processes concentrated in one region to some degree.

This observation has important implications for policy making. Industrial and innovation policies are still dominantly framed in a national context and implicitly assume that generating first-mover advantages in one dimension will positively affect all others (the feed-in tariff in Germany is a case in point for such a policy framed in a lead-market rationale (Quitzow, 2015)). Yet, as this paper and related studies show, the FIT did not lead to a sustained competitive advantage for the German PV industry in all value chain segments, but provided considerable spillovers to distant and late-following regions, especially China (Hoppmann et al., 2014; Quitzow, 2015). The same holds true for innovation policy approaches in the USA which aim at supporting basic science and $R \& D$ in new fields to create breakthrough innovation. The PV example shows that creating basic R\&D driven inventions and pioneering companies in an emerging industry is by no means a guarantee that significant manufacturing volumes and jobs will be retained in the same country in later industry lifecycle phases. National industrial, innovation or deployment policies accordingly need to be reflective of the current lifecycle stage of an industry and anticipate to some degree the differences in the spatial 'stickyness' of different segments of the value chain (Binz et al., under review; Schmidt and Huenteler, 2016).

Our study has several limitations that open interesting avenues for future research. First, the single case study design limits the generalizability of our results to sectors that share technology characteristics with solar PV manufacturing. Following the industry typology by 
Huenteler et al (Huenteler et al., 2014; Huenteler et al., 2016), we would expect similarly fluid spatial life-cycle dynamics to be most relevant for other industries with standardized massmanufactured goods and strong policy intervention, as e.g. in energy storage systems for households or for stationary fuel cells. In contrast, we would expect industries developing complex engineered systems for specialized users like wind turbines (Huenteler et al., 2016) ${ }^{6}$ to depend more strongly on co-location of manufacturing, knowledge creation and market deployment in all industry lifecycle phases (for an emblematic example see Garud and Karnoe, 2003).

Second, there are several well-documented limits to the type of data used in this study. The global databases especially for the patent analysis might be biased towards Western patent offices which do not include all relevant patents from Asian countries. We tried to overcome this problem by comparing the results of two independent databases, but improvements in the data coverage might still be possible. Also, recently emerging thin film and organic PV technologies were not in focus in this study. As their value chain differ significantly from crystalline technologies, additional studies would be needed to assess their specific spatial lifecycle dynamics. Fourth and finally, we observed generic differences in the patenting behavior among countries. E.g. Japanese companies seem to systematically patent more, but lower-quality patents than their European and American counterparts. Also, the surge in lowquality patenting in the Chinese case appears to be partly attributable to changes in national and regional innovation policies in the mid-2000s. Addressing these caveats could create promising improvements to the current state of the art in various disciplines such as innovation studies, economic geography and industrial dynamics literature.

\section{Conclusions and Policy Implications}

This paper asked the question whether traditional lifecycle theories for the spatial diffusion of innovation and manufacturing hold in a globalizing world economy and for

\footnotetext{
${ }^{6}$ Due to the tacit and systemic knowledge processes that dominate such industries, they evolve more strongly in one or a few key regions where architectural components are re-combined and tested in repeated and dense user-producer-inventor interaction.
} 
Binz, Tang, Huenteler - Spatial Dynamics in the Knowledge Base of Cleantech Sectors

emerging clean-tech sectors that depend heavily on policy interventions and demand-side dynamics. Based on an extensive analysis of patent, manufacturing and market deployment data in the global solar PV industry, we could show that the basic tenets of lifecycle models hold for the knowledge dimension, but that theories have to be adapted in three key ways: First, the traditional linear spatial diffusion models do not capture the high dynamism of today's more globalized manufacturing, and market deployment environment. In sectors like solar PV with internationally integrated global value chains and standardized mass markets, actors on several continents may get interrelated in developing new knowledge and technologies, manufacturing products and market opportunities (Binz et al., under review). To understand why, when and how new commercial activities emerge in new places, one thus has to explore in more detail how other factors than geographic proximity influence the spatial allocation of innovation and job creation.

Second, three hypotheses emerge from our results that could be tested in other sectors: 1) Catching-up in the knowledge dimension is most difficult, even in sectors with high spatial fluidity in the manufacturing and market deployment dimensions. 2) In the globalizing knowledge economy, late entrants can enter the manufacturing dimension already in the transition phase, leading to a temporal contraction of the lifecycle and higher shares of actors from emerging/developing countries in the manufacturing dimension. 3) The overall global lifecycle dynamics of an industry depend on related changes in its upstream and downstream value chain segments.

For industrial and innovation policy making, our results imply that the loss of parts of a value chain (e.g. loss of module manufacturing capacity from Western countries to China) does not automatically have detrimental effects on the competitiveness of the up- and downstream value chain segments. If other segments remain spatially sticky, first mover advantages can be transferred to other parts of the value chain. Given the high spatial complexity observed in the PV case, this study supports claims that more internationalized governance structures are needed that limit global free-riding and unequal distributions of costs and benefits in newly emerging sectors, especially in sustainability-related clean-tech sectors that rely on complex 
Binz, Tang, Huenteler - Spatial Dynamics in the Knowledge Base of Cleantech Sectors

spatial lifecycles which are strongly impacted by national and regional policy support (Gallagher, 2014; Peters et al., 2012; Quitzow, 2015).

\section{Acknowledgements}

The authors would like to thank the Sustainability Science Program at Harvard Kennedy School and the Swiss National Science Foundation (Early Postdoc.Mobility Grant P2BEP1_155474) for funding this project. Jan Ossenbrink and Karl Aspelund were an indispensable support in data collection, preparation and analysis. We would also like to acknowledge the constructive input from Gabriel Chan at the 2015 Fall Research Conference of Association for Public Policy Analysis and Management in Miami. This work was partly conducted while Christian Binz and Tian Tang were Giorgio Ruffolo Fellows in the Sustainability Science Program at Harvard University. Support from Italy's Ministry for Environment, Land and Sea is gratefully acknowledged.

\section{References}

Abernathy, W.J., Utterback, J.M., 1988. Innovation over time and in historical context. In: Tushman, M.L., Moore, W.L. (Eds.), Readings in Management Innovation. Harper Collins Publishers, New York, pp. 25-36.

Abernathy, W.J., Utterback, J.M., 1978. Patterns of Industrial Innovation. Technology Review 80 (7), 40-47.

Anadón, L.D., 2012. Missions-oriented RD\&D institutions in energy between 2000 and 2010: A comparative analysis of China, the United Kingdom, and the United States. Research Policy 41 (10), 1742-1756.

Anderson, P., Tushman, M.L., 1990. Technological Discontinuities and Dominant Designs: A Cyclical Model of Technological Change. Administrative Science Quarterly 35 (4), 604-633.

Asheim, B.T., Coenen, L., Vang, J., 2007. Face-to-face, buzz, and knowledge bases:

Sociospatial implications for learning, innovation, and innovation policy. Environment and Planning C: Government and Policy 25 (5), 655-670.

Audretsch, D.B., Feldman, M.P., 1996. Innovative clusters and the industry life cycle. Review of Industrial Organization 11 (2), 253-273.

Beise, M., Rennings, K., 2005. Lead markets and regulation: A framework for analyzing the international diffusion of environmental innovations. Ecological Economics 52 (1), 5-17. 
Binz, Tang, Huenteler - Spatial Dynamics in the Knowledge Base of Cleantech Sectors

Bento, N., Fontes, M., 2015. Spatial diffusion and the formation of a technological innovation system in the receiving country: The case of wind energy in Portugal. Environmental Innovation and Societal Transitions 15, 158-179.

Binz, C., Truffer, B., Coenen, L., under review. Global Innovation Systems - towards a conceptual framework for technological innovation in transnational contexts. Under review at Research Policy.

Binz, C., Diaz Anadon, L., under review. Industry transplantation as a new catching-up model? The emergence of the Chinese solar PV industry. Under review at Research Policy.

Binz, C., Truffer, B., Coenen, L., 2014. Why space matters in technological innovation systems - The global knowledge dynamics of membrane bioreactor technology. Research Policy 43 (1), 138-155.

Boschma, R., 2005. Proximity and innovation: a critical assessment. Regional Studies 39 (1), 61-74.

Boschma, R.A., Martin, R., 2010. The aims and scope of evolutionary economic geography. In: Boschma, R., Martin, R. (Eds.), The handbook of evolutionary economic geography. Edward Elgar, Cheltenham, pp. 3-39.

Bunnell, T.G., Coe, N.M., 2001. Spaces and scales of innovation. Progress in Human Geography 25 (4), 569-589.

Crevoisier, O., Jeannerat, H., 2009. Territorial knowledge dynamics: From the proximity paradigm to multi-location milieus. European Planning Studies 17 (8), 1223-1241.

de la Tour, A., Glachant, M., Ménière, Y., 2011. Innovation and international technology transfer: The case of the Chinese photovoltaic industry. Energy Policy 39 (2), 761-770.

Dewald, U., Truffer, B., 2011. Market Formation in Technological Innovation Systems Diffusion of Photovoltaic Applications in Germany. Industry and Innovation 18 (3), 285-300.

Dewald, U., Fromhold-Eisebith, M., 2015. Trajectories of sustainability transitions in scaletranscending innovation systems: The case of photovoltaics. Environmental Innovation and Societal Transitions 17, 110-125.

Dicken, P., 2007. Global shift: mapping the changing contours of the world economy - 5th edition. The Guilford Press, New York.

Ernst, D., 2002. Global Production Networks and the Changing Geography of Innovation Systems. Implications for Developing Countries. Economics of Innovation and New Technology 11 (6), 497-523.

Gallagher, K.S., 2014. The Globalization of Clean Energy Technology - Lessons from China. MIT press, Cambridge, MA.

Gallagher, K.S., Zhang, F., 2013. Innovation and Technology Transfer Across Global Value Chains: Evidence from China's PV Industry. Climate \& Development Knowledge Network, Tufts University.

Garud, R., Karnoe, P., 2003. Bricolage versus breakthrough: distributed and embedded agency in technology entrepreneurship. Research Policy 32 (2), 277-300. 
Binz, Tang, Huenteler - Spatial Dynamics in the Knowledge Base of Cleantech Sectors

Gereffi, G., 1999. International trade and industrial upgrading in the apparel commodity chain. Journal of International Economics 48 (1), 37-70.

Goodrich, A.C., Powell, D.M., James, T.L., Woodhouse, M., Buonassisi, T., 2013. Assessing the drivers of regional trends in solar photovoltaic manufacturing. Energy and Environmental Science 6 (10), 2811-2821.

Gress, D.R., 2014. Enrolling in global networks and contingencies for China's solar PV industry. Asia Pacific Business Review.

Harhoff, D., Scherer, F.M., Vopel, K., 2003. Citations, family size, opposition and the value of patent rights. Research Policy 32 (8), 1343-1363.

Hoppmann, J., Huenteler, J., Girod, B., 2014. Compulsive policy-making-The evolution of the German feed-in tariff system for solar photovoltaic power. Research Policy 43 (8), 1422-1441.

Huenteler, J., Schmidt, T., Ossenbrink, J., Hoffmann, V., 2016. Technology Life-Cycles in the Energy Sector - Technological Characteristics and the Role of Deployment for Innovation. Technological Forecasting \& Social Change 104, 102-121.

Huenteler, J., Ossenbrink, J., Schmidt, T.S., Hoffmann, V.H., 2014. How a Product's Design Hierarchy Shapes the Evolution of Technological Knowledge-Evidence from Patent-Citation Networks in Wind Power. Available at SSRN 2534072.

Huenteler, J., Ossenbrink, J., Schmidt, T.S., Hoffmann, V.H., 2016. How a product's design hierarchy shapes the evolution of technological knowledge - Evidence from patent-citation networks in wind power. Research Policy 45 (6), 1195-1217.

Huenteler, J., Schmidt, T.S., Kanie, N., 2012. Japan's post-Fukushima challenge - implications from the German experience on renewable energy policy. Energy Policy 45, 6-11.

Jänicke, M., Jacob, K., 2004. Lead markets for environmental innovations: a new role for the nation state. Global environmental politics 4 (1), 29-46.

Jeannerat, H., Kebir, L., 2016. Knowledge, Resources and Markets: What Economic System of Valuation? Regional Studies 50 (2), 274-288.

Klepper, S., 1996. Entry, Exit, Growth, and Innovation over the Product Life Cycle. American Economic Review 86 (3), 562-583.

Klepper, S., Graddy, E., 1990. The evolution of new industries and the determinants of market structure. RAND Journal of Economics 21 (1), 27-44.

Lanjouw, J.O., Pakes, A., Putnam, J., 1998. How to Count Patents and Value Intellectual Property: The Uses of Patent Renewal and Application Data. The Journal of Industrial Economics 46 (4), 405-432.

Lema, R., Lema, A., 2012. Technology transfer? The rise of China and India in green technology sectors. Innovation and Development 2 (1), 23-44.

Lewis, J.I., 2011. Building a national wind turbine industry: Experiences from China, India and South Korea. International Journal of Technology and Globalisation 5 (3-4), 281-305. 
Binz, Tang, Huenteler - Spatial Dynamics in the Knowledge Base of Cleantech Sectors

Lundvall, B., 1992. National Systems of Innovation - toward a Theory of Innovation and Interactive Learning. Pinter, London.

Lundvall, B., Johnson, B., Andersen, E.S., Dalum, B., 2002. National systems of production, innovation and competence building. Research Policy, 31 (2), 213-231.

Malerba, F., 2006. Innovation and the evolution of industries. Journal of Evolutionary Economics 16 (1-2), 3-23.

Morrison, A., Pietrobelli, C., Rabellotti, R., 2008. Global value chains and technological capabilities: a framework to study learning and innovation in developing countries. Oxford development studies 36 (1), 39-58.

Moulaert, F., Sekia, F., 2003. Territorial Innovation models: A critical survey. Regional Studies 37 (3), 289-302.

Murmann, J.P., Frenken, K., 2006. Toward a systematic framework for research on dominant designs, technological innovations, and industrial change. Research Policy 35 (7), 925-952.

Nahm, J., Steinfeld, E.S., 2014. Scale-up Nation: China's Specialization in Innovative Manufacturing. World Development 54, 288-300.

Neffke, F., Henning, M., Boschma, R., 2011. How Do Regions Diversify over Time? Industry Relatedness and the Development of New Growth Paths in Regions. Economic Geography 87 (3), 237-265.

Peters, M., Schneider, M., Griesshaber, T., Hoffmann, V.H., 2012. The impact of technologypush and demand-pull policies on technical change-Does the locus of policies matter? Research Policy 41 (8), 1296-1308.

Pietrobelli, C., Rabellotti, R., 2009. The global dimension of innovation systems: linking innovation systems and global value chains. In: Lundvall, B., Joseph, K.J., Chaminade, C., Vang, J. (Eds.), Handbook of Innovation Systems and Developing Countries. Edward Elgar, Cheltenham, UK, pp. 214-238.

Quitzow, R., 2013. The Co-evolution of Policy, Market and Industry in the Solar Energy Sector - A Dynamic Analysis of Technological Innovation Systems for Solar Photovoltaics in Germany and China . FFU Report 06 - 2013, Forschungszentrum für Umweltpolitik, Freie Universität Berlin.

Quitzow, R., 2015. Dynamics of a policy-driven market: The co-evolution of technological innovation systems for solar photovoltaics in China and Germany. Environmental Innovation and Societal Transitions 17, 126-148.

Schmidt, T.S., Huenteler, J., 2016. Anticipating industry localization effects of clean technology deployment policies in developing countries. Global Environmental Change 38, 8-20.

Sengers, F., Raven, R., 2015. Toward a spatial perspective on niche development: The case of Bus Rapid Transit. Environmental Innovation and Societal Transitions 17, 166-182.

Storper, M., Walker, R., 1989. The capitalist imperative - Territory, Technology, and industrial Growth. Basil Blackwell, New York.

Storper, M., 1997. The Regional World. Guilford Press, New York. 
Suarez, F., Utterback, J., 1993. Patterns of industrial evolution, dominant designs, and firms' survival. In: Burgelman, R., Rosenbloom, R.S. (Eds.), Research on technological innovation, Management and Policy. JAI Press, Greenwich, CT, pp. 79-92.

Utterback, J.M., Abernathy, W.J., 1975. A dynamic model of process and product innovation. Omega 3 (6), 639-656.

Varadi, P., 2014. Sun Above the Horizon: Meteoric Rise of the Solar Industry. Pan Stanford Publishing, Singapore.

Vasseur, V., Kamp, L.M., Negro, S.O., 2013. A comparative analysis of Photovoltaic Technological Innovation Systems including international dimensions: The cases of Japan and the Netherlands. Journal of Cleaner Production 48, 200-210.

Vernon, R., 1966. International investment and international trade in the product cycle. The quarterly journal of economics, 190-207.

Zhang, F., Gallagher, K.S., 2016. Innovation and technology transfer through global value chains: Evidence from China's PV industry. Energy Policy 94, 191-203. 
Binz, Tang, Huenteler - Spatial Dynamics in the Knowledge Base of Cleantech Sectors

Figure 1: Global distribution of manufacturing output shares

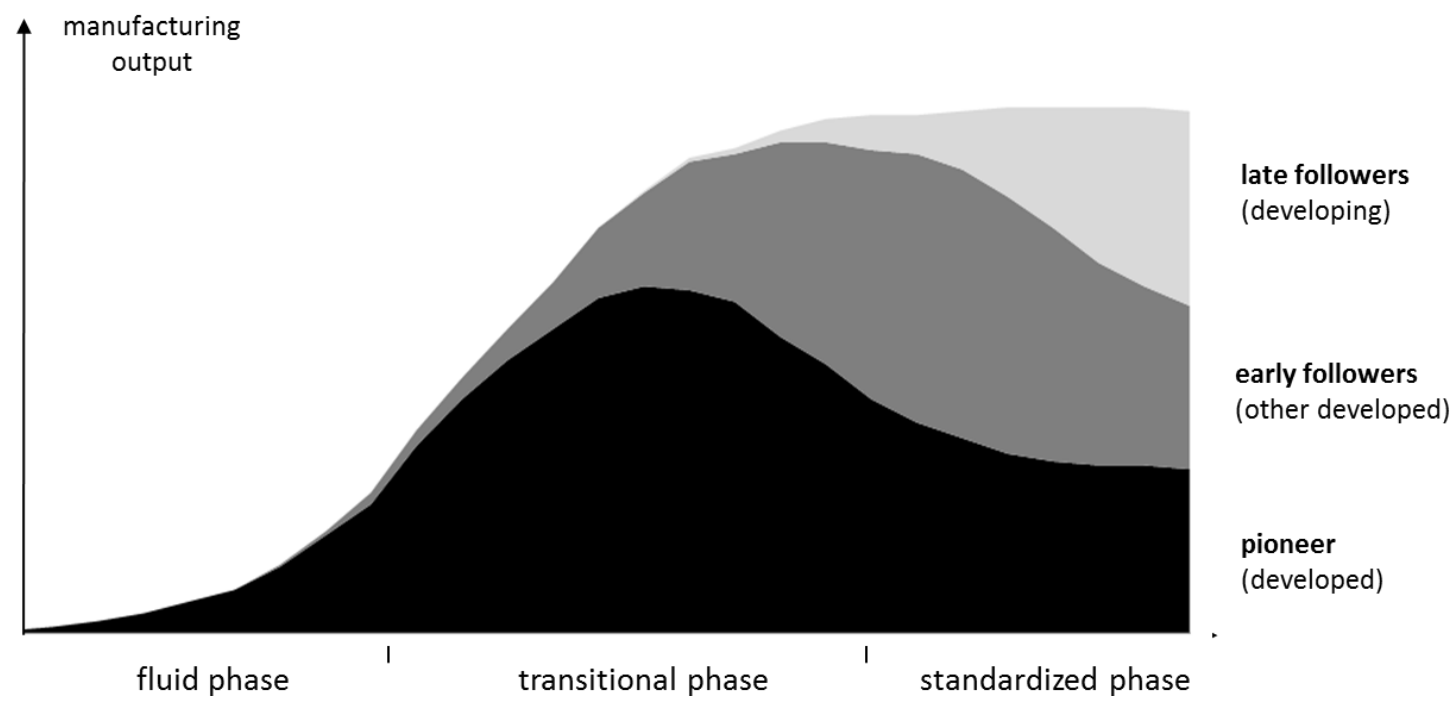

Source: own design, based on (Vernon, 1966) 
Figure 2: Global distribution of market deployment

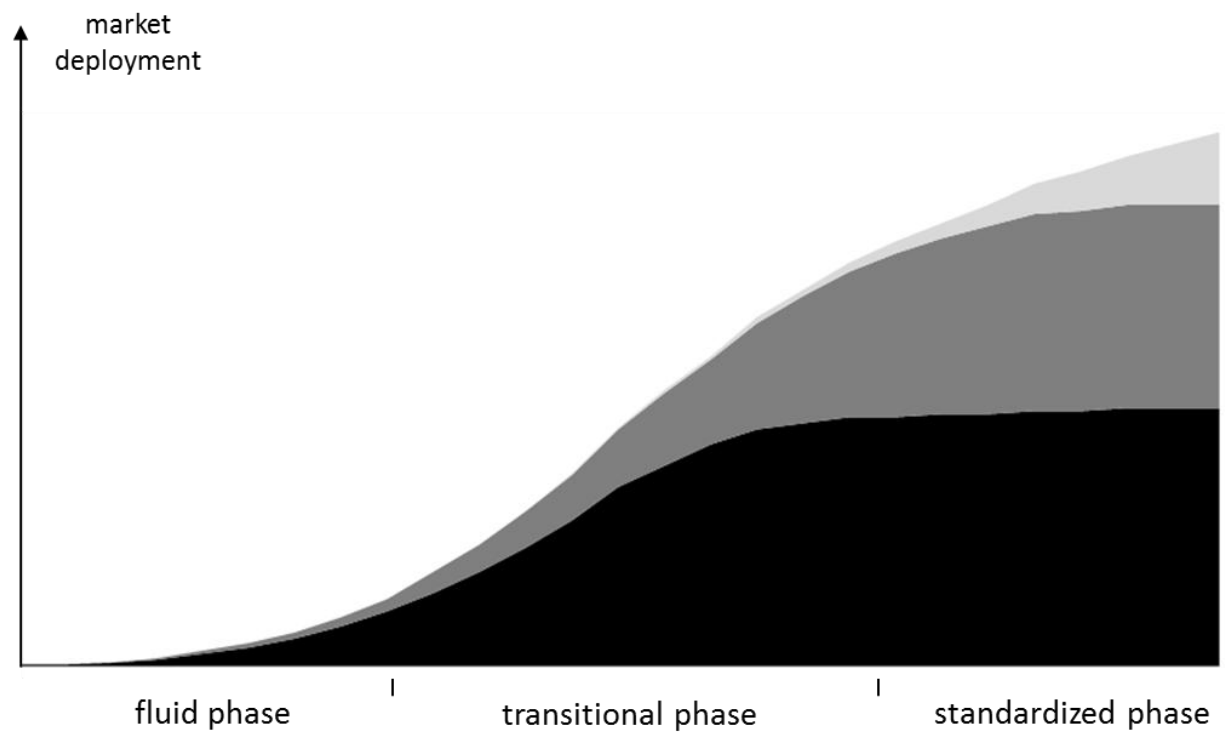

late followers

(developing)

early followers

(other developed)

Source: own design, based on (Beise and Rennings, 2005; Vernon, 1966) 
Figure 3: Spatial lifecycle of knowledge base

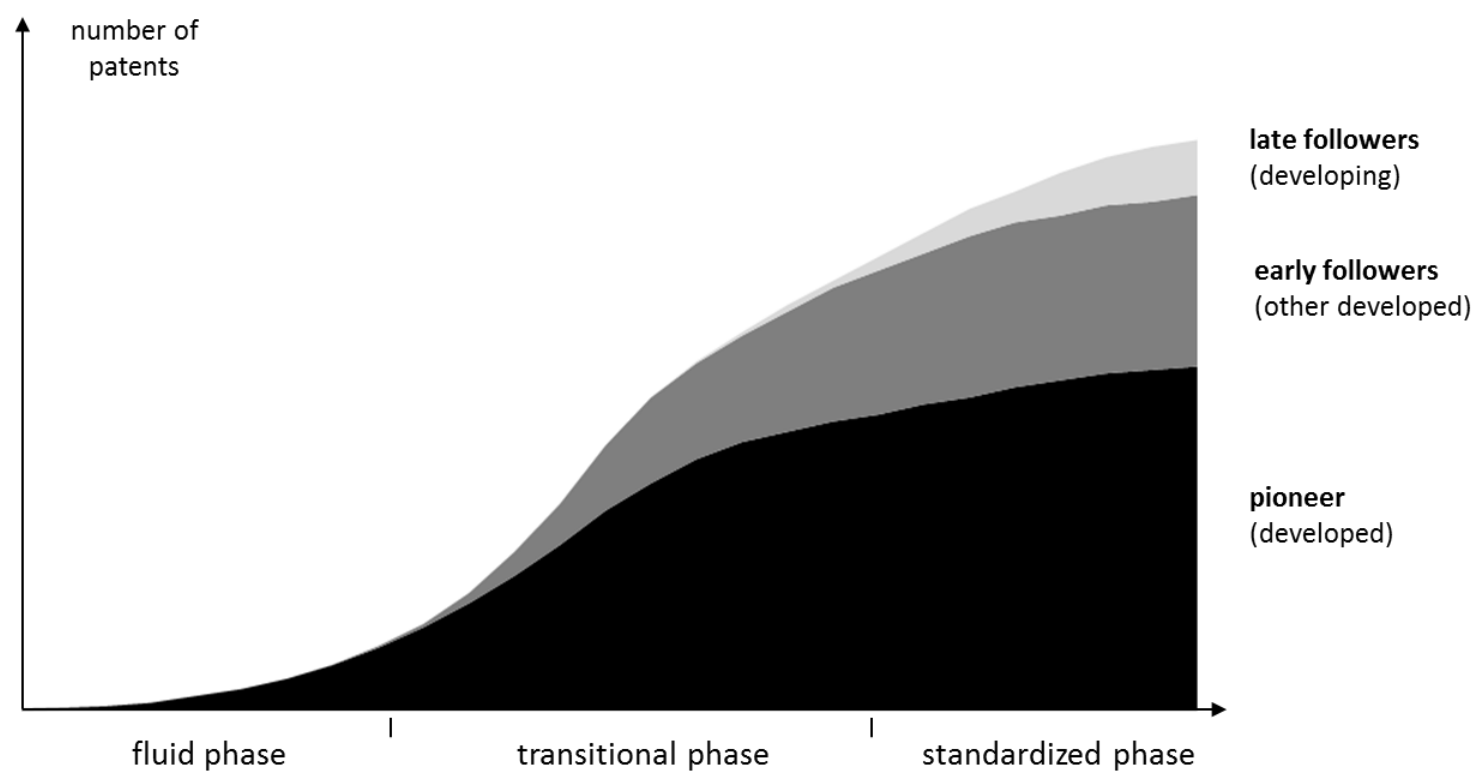

Source: own design, based on (Audretsch and Feldman, 1996) 
Figure 4: Global Solar PV Cell Manufacturing: Annual Production, Manufacturing Shares, and Major Manufacturing Countries
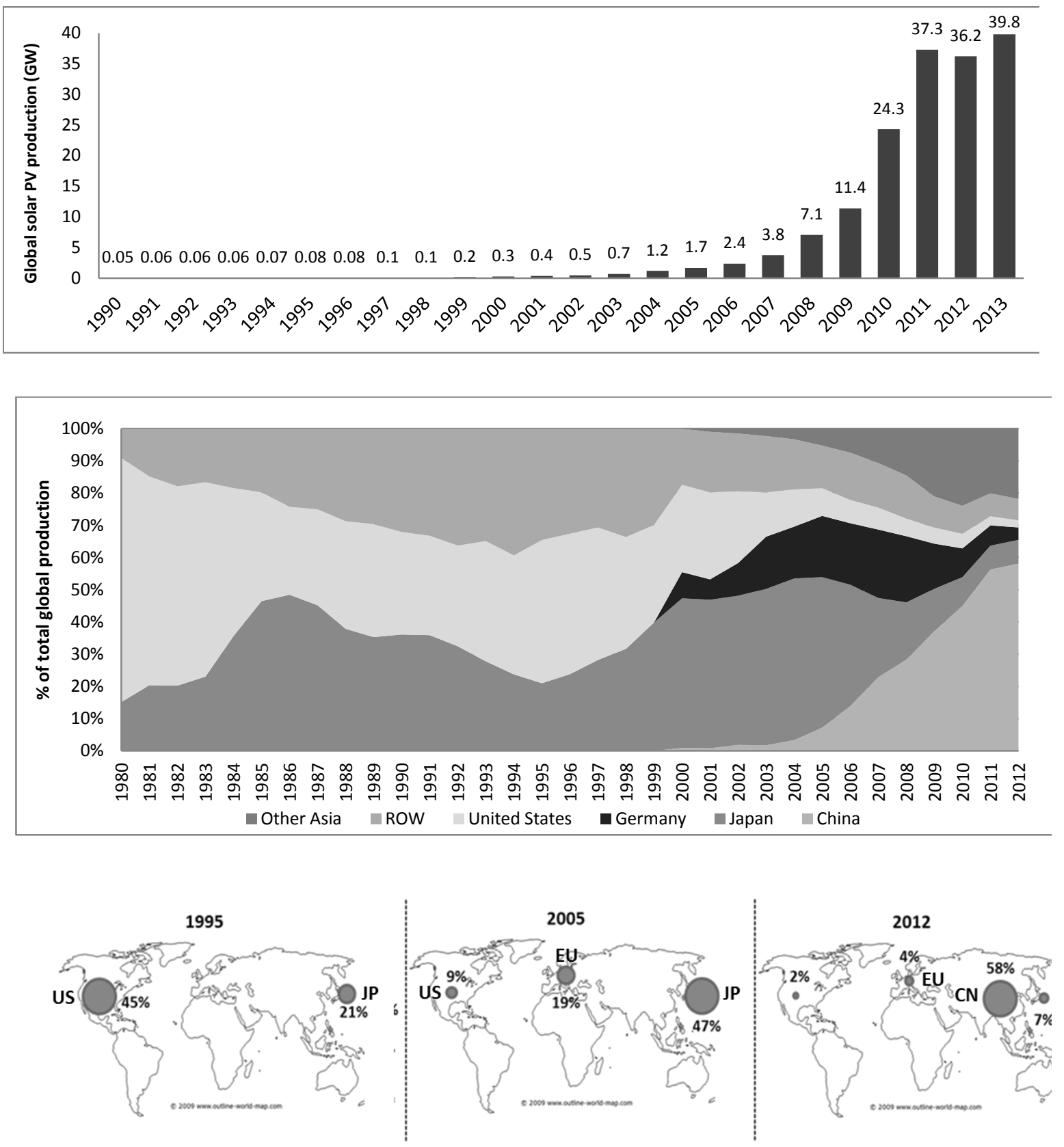

Source: Own design, based on data from Earth Policy Institute (EPI, 2013) and the Office of Technology Assessment (OTA, 1995). Note: 1) We did not include the data points from 1980 to 1989 in the first figure. The annual global solar PV production in these 10 years was $20 \mathrm{MW}$ on average. 2) Data on solar PV production in Germany is only available since 2000. We have data on solar PV production in Europe between 1980 and 2000, which accounts for the majority of the solar PV production in the rest of the world (ROW) each year. 
Figure 5: Global Solar PV Market: Annual Installation, Market Share, and Major Markets
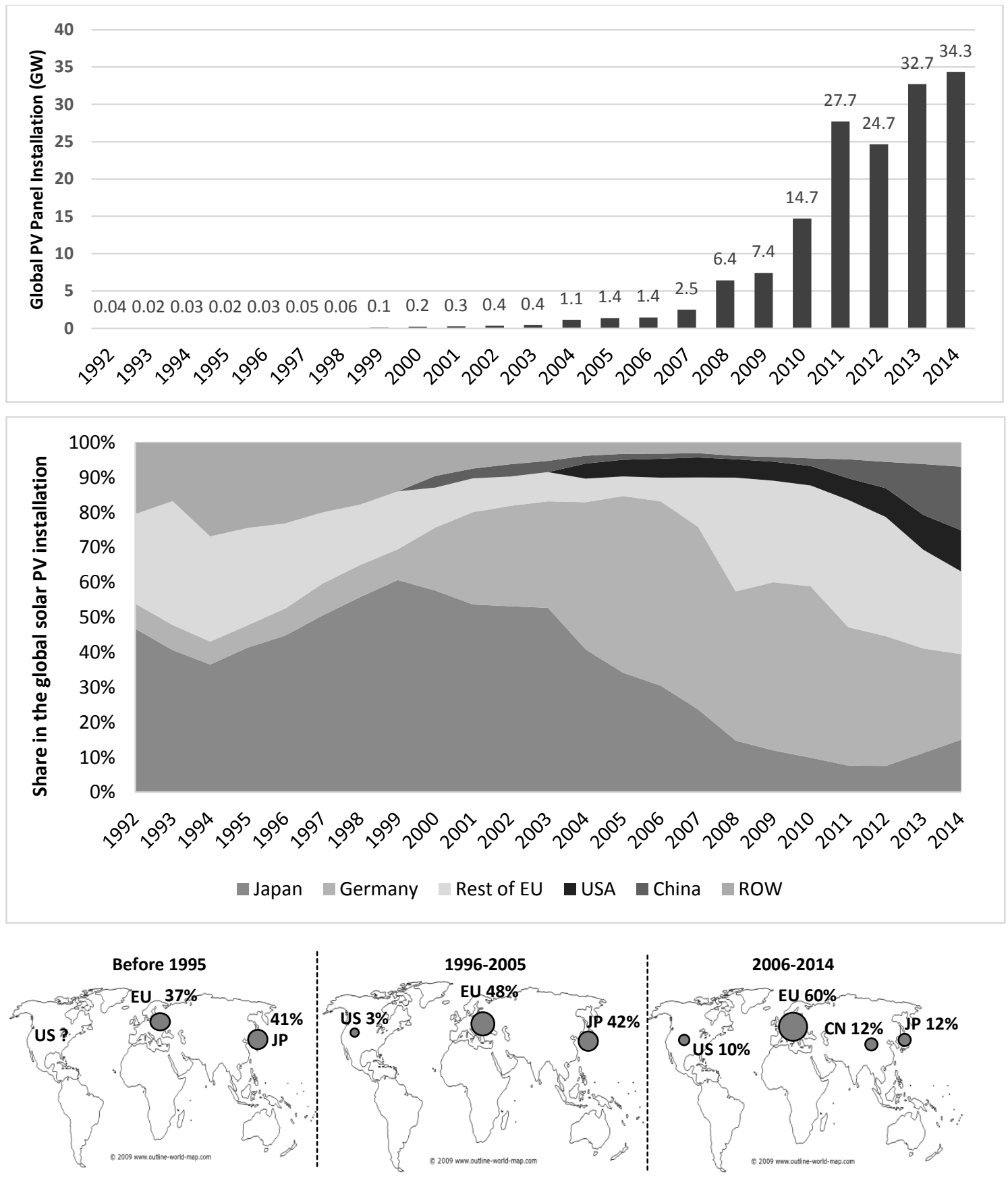

Source: Own design, based on data from International Energy Agency (IEA-PVPS, 2015) 
Figure 6: PV Knowledge Creation: Annual Patenting, Country Shares, and Major Knowledge Bases
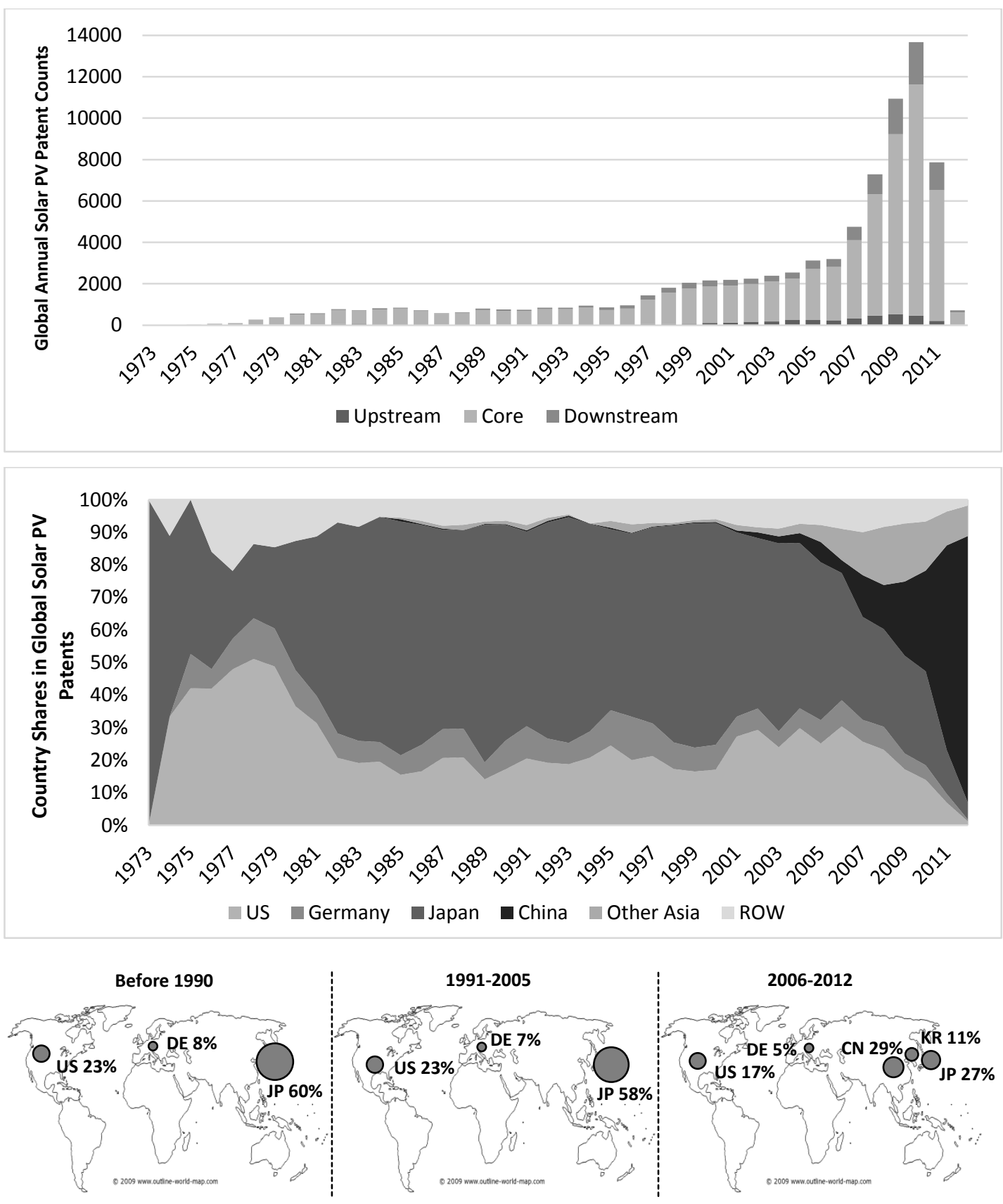

Source: Own design, based on data derived from Thomson Innovation and Derwent Global Patent databases. Note: 1) The size of the dots in the bottom figure indicates the share of global patents that the major knowledge generating countries during each phase in the PV industry lifecycle. 2) It usually takes one to three years from the first patent application to its publication. Since our data was collected in 2013, some patent applications originally filed in 2012 may not be published yet. Our results might thus underestimate the full amount of patents that were published in 2012. 3) We did not include data points before 1973 since there were only two patents in 1965 and 1969. 
Figure 7: Positions of Major Knowledge Bases in Patent Quality-Quantity Matrix

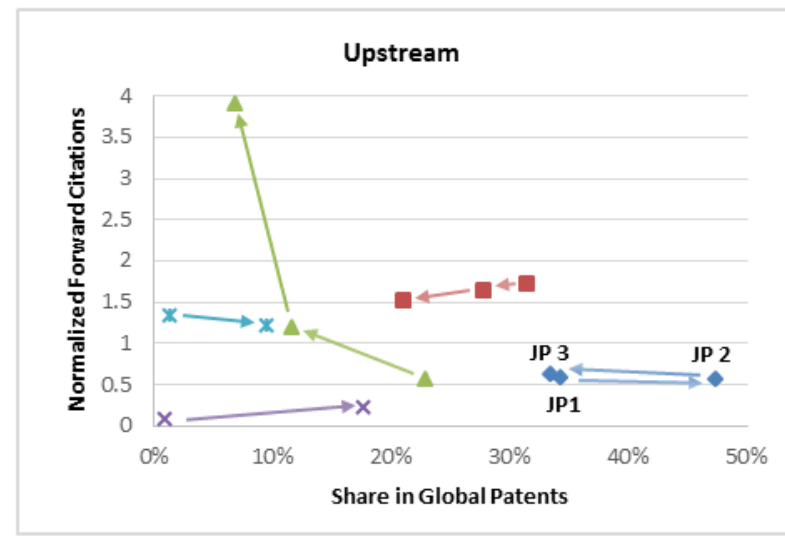

1a)

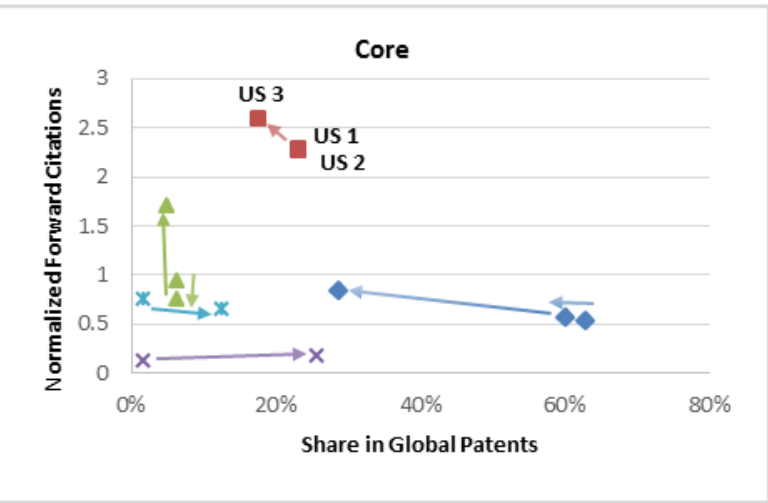

2a)

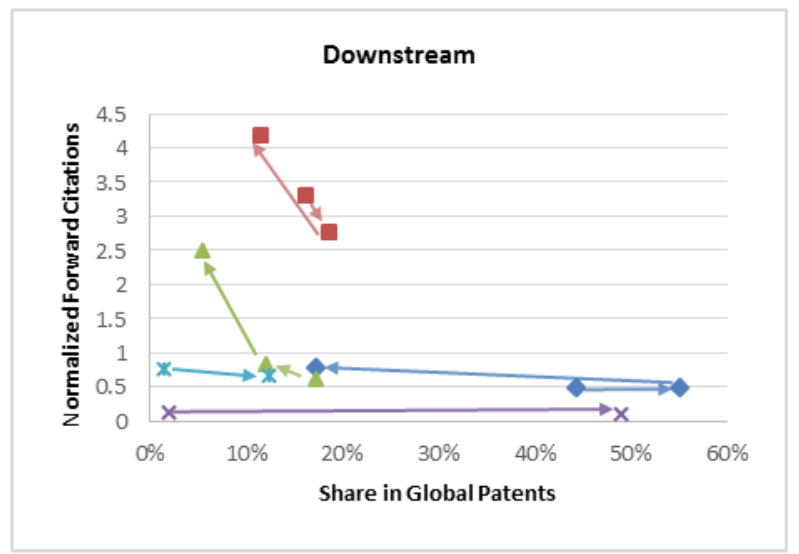

3a)

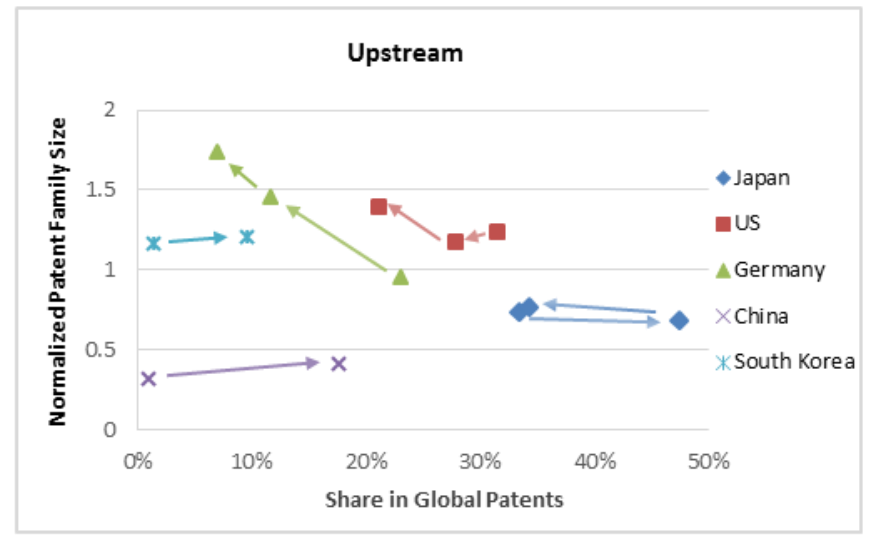

1b)

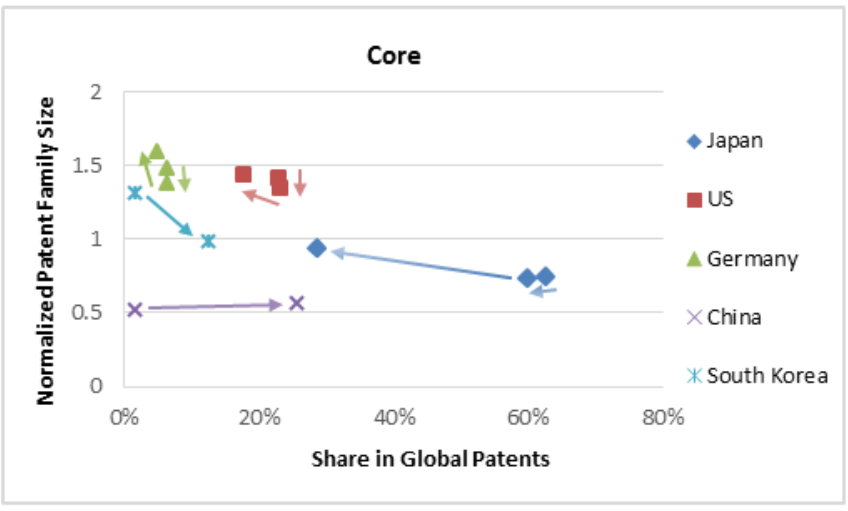

2b)

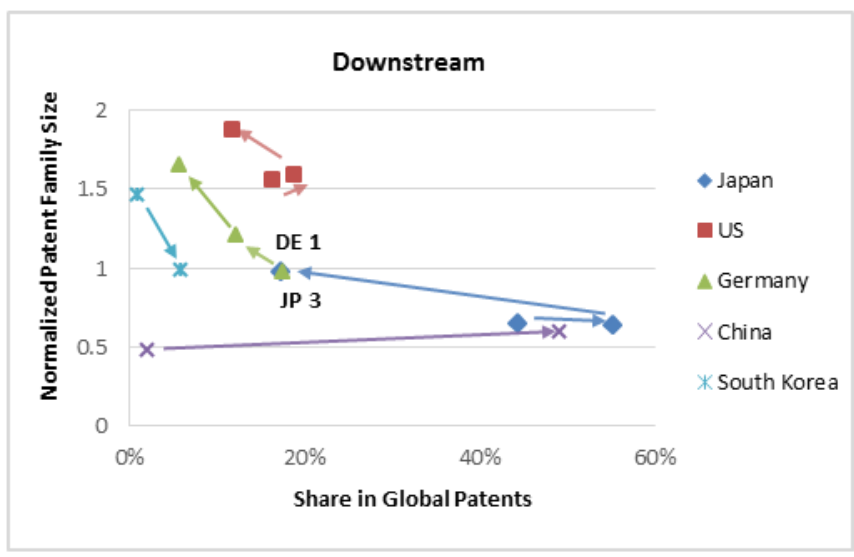

3b)

Source: Own design, based on data derived from Thomson Innovation and Derwent Global Patent databases. Notes: 1) The figures show positions data for all three lifecycle phases (i.e. average measures for the fluid phase, 1965-1990; the transitional phase, 1991-2005; and the standardized phase, after 2005) for Japan, US, and Germany since they were the major players in all three phases. For China and South Korea, significant data is only available in phase 2 and phase 3. Arrows indicate the evolution of knowledge creation in each of the three phases. 2) In Figure 2a), the US has very close positions in phase 1 and phase 2 (indicated as "US1" and US2") 3) In Figure 3b), the dot for Japan Phase 3 (“JP3") and the dot for Germany phase 1 ("DE1") overlap 
Binz, Tang, Huenteler - Spatial Dynamics in the Knowledge Base of Cleantech Sectors

Table 1: Allocation of patent classes to solar PV value chain segments

\begin{tabular}{lll}
\hline Value chain segment & Description & Examples of IPC classes \\
\hline Upstream & Highly purified silicon, & C01B - non-metallic elements, silicon \\
& $\begin{array}{l}\text { silicon doping processes, }, \\
\text { ingot casting and wafer }\end{array}$ & C23C - metallic coating, surface treatment \\
& C30B - single-crystal growth \\
& cutting & B28D - Sawing of Si-ingots \\
Core & Cell manufacturing, & B23K - welding, soldering \\
& welding, module & H01B - cables, conductors \\
manufacturing and & H01L - semiconductors, cell manufacturing \\
& testing & G02B - Optical elements, systems, or apparatus \\
Downstream & Grid integration, rooftop & H02M - inverters \\
& installation, balance of & E04D - roof covers \\
& systems and maintenance & H01M - batteries \\
& & H02J - power distribution, DC/AC
\end{tabular}

Data on solar PV cell manufacturing was derived from the Earth Policy Institute online database (EPI, 2013) and the report from the Office of Technology Assessment (OTA, 1995). Data on PV market deployment was collected from the International Energy Agency’s 2015 solar PV survey report (IEA-PVPS, 2015). 